\title{
ALTERNATE HOST PLANTS OF THE PINK BOLLWORM, PECTINOPHORA GOSSXPIELLA (SAUND.), IN PUERTO RICO
}

By L. Courtenex Fife, U. S. Department of Agriculture, Bureau of Entomology and Plant Quarantine ${ }^{1}{ }^{2}$

\section{INTRODUCTION}

A knowledge of the importance that alternate host plants play in the perpetuation of the pink bollworm, Pectinophora gossypiella (Saund.), from one cotton crop to the next is valuable in formulating methods for its control. Heretofore this problem has been little studied in Puerto Rico.

Puerto Rico is comparatively rich in Malvaceae, the only family of plants that has been found to include species attacked by this pest, 19 genera and 59 species having been recorded. Other than cotton. however, only 5 genera and 9 species of food plants of the pink bollworm are found on the Island. The importance of each of these food plants in maintaining the pink bollworm in the absence of cultivated cotton is briefly discussed in the following notes.

\section{MoNTEZUMa}

Maga, Montezuma speciosissima, is a tree endemic to Puerto Rico. It has been planted along roadsides as an ornamental and for shade, but it is also found on waste land in mountain ranges. The tree is most abundant in the cotton-growing region on the north coast between Aguadilla and San Juan. The wood is used in making fur. niture, interior woodwork, musical instruments, fence posts, etc. The large. showy flowers are bright red and remain on the plant several days after opening. Every tree bears numerous seed capsules which average $1 \frac{1}{2}$ inches in length and $1 \frac{1}{4}$ inches in diameter, and each pod contains several naked seeds.

The relation between the time of abundance of mature seed capsules on this tree and the seasons of cotton production on the north coast is shown in Figure 1. It will be noted that few or no mature seed capsules are found on this plant during June, July, August,

\footnotetext{
${ }^{1}$ Working in cooperation with the Puerto Rico Experiment Station of the United States Department of Agriculture.

${ }^{2}$ The writer is greatly indebted to Mr. José Otero, Librarian of the Insular Experiment Station, for the identification of the various plants mentioned in this publication.
} 
and September. Buds and flowers, however, are produced in abundance during the entire year.

Counts for pink bollworm infestation were made in the fruiting forms of maga during the first week of each month from November 1936 to May 1937, inclusive. The area surveyed included most oi: the commercial cotton-growing districts along the north coast between Aguadilla and Camuy (43 kilometers). Large samples of pods and buds were taken about every $2 \frac{1}{2}$ kilometers in this area.

The results of examination of the mature seed capsules are summarized in Table 1 and graphically illustrated in Figure 1 . It will be noted that the average percentage of infested seed capsules gradually decreased from 30 percent in November 1936 to 1.1 percent in May 1937. The highest percentage of infested pods was 54.3 percent, recorded in November at Camuy. Even as late as April the pod infestation averaged 10.6 percent, ranging from 2 percent at Isabela to 28 percent at Aguadilla. Also, of 100 pods examined at Camuy in March 1937, 41 percent were found infested. It will also be noted that the infestation was highest on Montezuma speciosissima during the dead season of cotton production, i. e., from September 30 to January 1 . The mature seed capsules, however, are most numerous during the planting season. They gradually decrease in numbers and by June become very scarce. As shown in Figure 1 , the infestation is carried over on these pods well into the growing period of cotton.

At Isabela, Wolcott (1936) found maga pods continuously infested from September 1931 to June 1932, the infestation ranging from 90 percent in October to 5 percent in March. $\mathrm{He}$ examined about two samples per month during this period and all were infested.

The results of pink bollworm infestation counts in large buds of maga from December 1936 to March 1937 on the north coast between Aguadilla and Camuy are summarized in Table 2. The average number of buds found infested was as follows: December, 16.5 percent; January, 9.3 percent; February, 4 percent; and March, 0.4 percent. The highest infestation in buds was 35.3 percent in December at Isabela. It will also be noted that buds were not so heavily infested as the pods, the ratio being about 1 to 4 . 


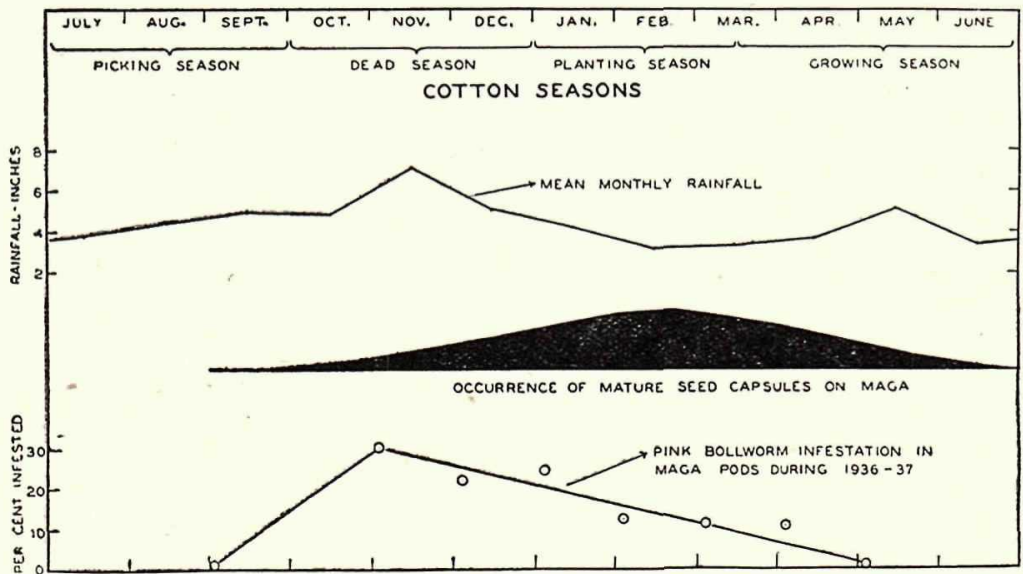

FIGURE 1.-Relation between the planting, growing, picking, and dead seasons of cotton production; mean monthly rainfall distribution; occurrence of mature seed capsules on maga, Montezuma speciosissima; and pink bollworm infestation in maga pods during 1936-37 in the cotton area on the north coast of Puerto Rico.

TABLe 1-Pink bollworm infestation in the mature seed Capsules of Montezuma speciossima on the north const of Puerto Rico between aguadilla and Camuy from NovemBER 1936 TO MAY 1937, INCLUSIVE *

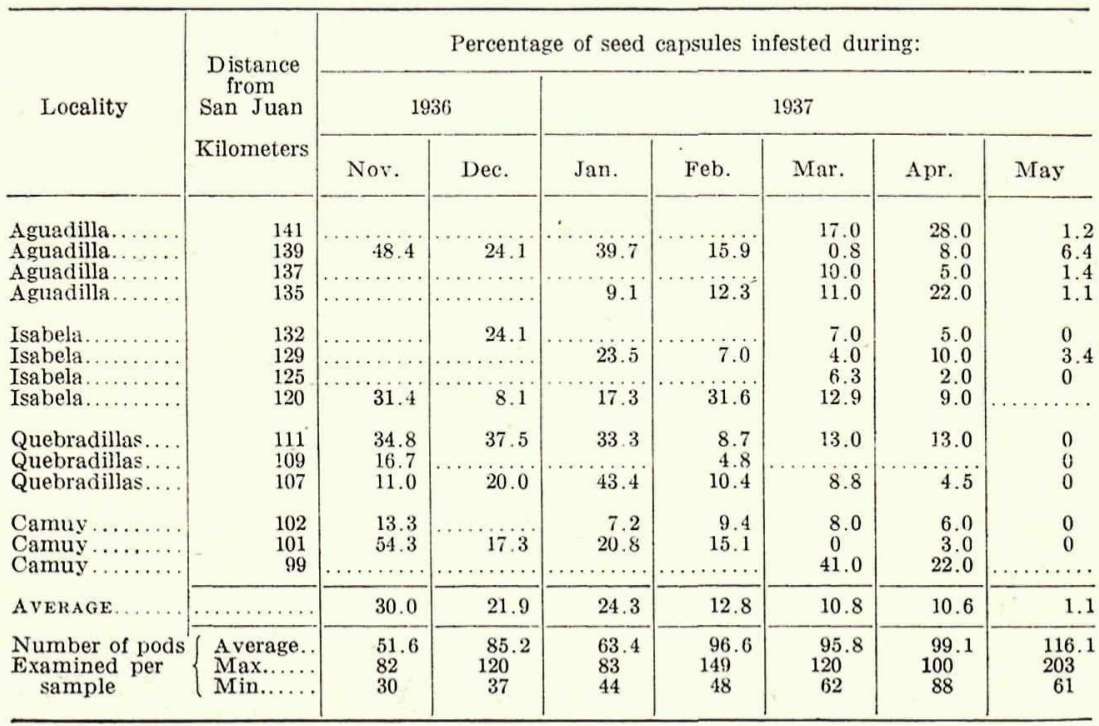

(*) All seed capsules were collected and examined during the first week of each month. 
TABle 2-Pint bollworm infestation in LARge buds of Montezuma speciosissima on the North Coast of Puerto Rico between Aguadilia and Camuy from Jecember 1936 to March 1937, inclusive. *

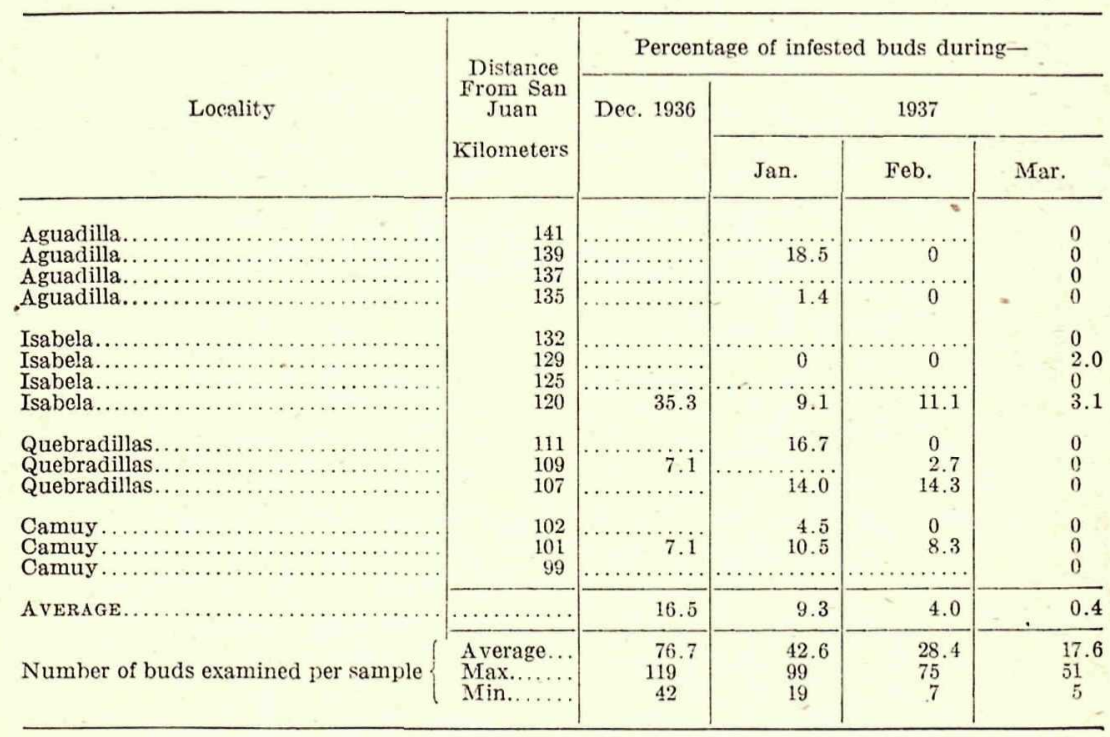

$\left(^{*}\right)$ All buds were examined during the first week of each month.

As many as four mature larvae have been found in one seed capsule and three in one bud. In the pods the larvae feed almost entirely inside the seeds, hollowing-out their contents. When the larvae become mature they may tunnel to the outside or remain in the seeds to pupate.

As shown also in Figure 1, the picking season on the north coast occurs during a period of heavy rainfall and the planting season during the driest period. Mr. U. C. Loftin, in an unpublished report submitted in 1931, recommended a reversal of the seasons of cotton production in this area so that the planting season would occur during the period of heaviest rainfall and the picking season during the driest period, thereby establishing uniform cotton seasons for the entire island. A further study of this problem by the writer (1937) suggested that the seasons of cotton production be adjusted so that the dead season would coincide with the period when very few seed capsules occur on maga, i. e., from May 1 to July 31 of each year. If this were done the pink bollworm would be more limited in finding suitable fruiting forms on maga in which to breed up in large numbers during the dead season between one cotton crop and the next. If such 
changes were effected the planting season would also coincide with the period of greatest rainfall and the picking season with the driest period. The growers would greatly benefit by such a practice, since a reduction in the pink bollworm infestation would permit them to produce more cotton of a superior quality.

\section{THESPESIA}

Thespesia populnea (emajagüilla) is a wild tree which occurs in waste places on the lower coastal plains, particularly on the south coast between Cabo Rojo and Ponce. It has been planted along roadsides as an ornamental and for shade. Fruiting forms in all stages of development may be found on this plant during the entire year. The mature seed eapsules average about 1 inch in length and about $1 \frac{1}{2}$ inches in diameter, and each pod contains several naked seeds.

Numerous seed capsules were examined throughout the closed season of cotton production on the north coast in 1936 and 1937. As shown in Table 3, the mature green pods were found infested from September 1936 to March 1937. During this entire period the infestation averaged 3.4 percent, the highest being 14.3 percent. Thespesia populnea does not, however, become infested until after the cotton has been destroyed at the end of the season. These data show that the pink bollworm will successfully maintain itself on this host plant in the absence of cotton for 4 or 5 months.

This tree has previously been reported as a host plant of Pectinophora gossypiella in Hawaii by Fullaway (1909) and Willard (1927), in the Virgin Islands by Loftin (1931, and in Puerto Rico hy Wolcott and Seín (1931).

Table 3-Pink bollworm infestation in the mature green seed capsules of Thespesia populnea on the north const of PUerto Rico from September 1936 to April 1937, inclusive.

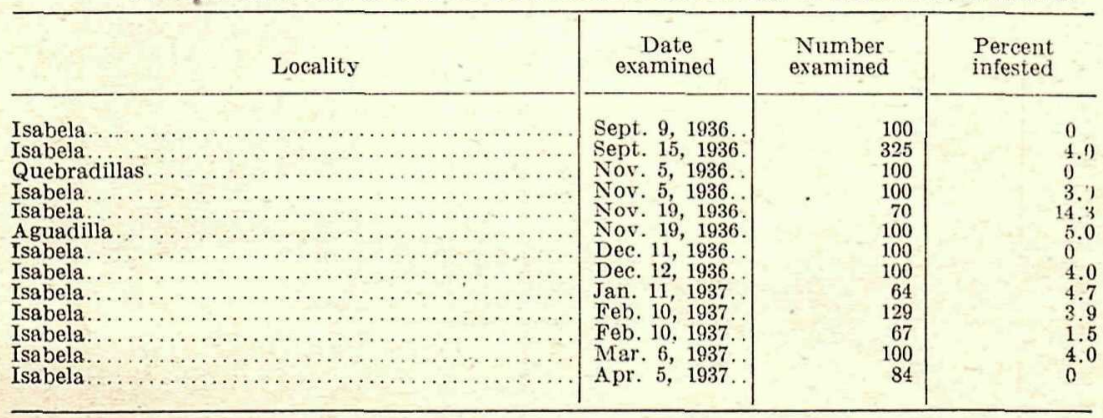




\section{Abelmoschus}

Okra, Abelmoschus esculentus, is cultivated quite extensively in all parts of the Island. Since pod infestations of okra as high as 50 to 90 percent have been recorded in other countries when this crop was growing adjacent to heavily infested cotton, it is considered a rather favorable host plant of the pink bollworm. Wolcott (1931) reports that even young pods may become infested. when nearby cotton is infested, necessitating quarantine regulations against its exportation. Consequently, as a means of controlling the pink bollworm, it would seem logical to avoid the growing of okra during the closed season of cotton production.

Okra has also been reported as a host plant of Pectinophora gossypiella in Mexico by Loftin et al (1921), Ohlendorf (1926), and Rude (1932), in Egypt by Willeocks (1916), in Africa by Taylor (1936), in the Virgin Islands by Loftin (1931), and in Austraija by Holdaway (1926).

Algalia, Abelmoschus abelmoschus, is occasionally grown in Puerto Rican gardens for its musk-scented seeds and for medicinal purposes. The large bristly seed pods average around $23 / 4$ inches in length and $11 / 4$ inches in diameter. Of 129 pods collected adjacent to infested cotton at Isabela, 10, or 7.8 percent, were found infested. First-instar pink bollworm larvae were artificially installed on 20 mature green seed capsules and 10, or 50 percent, became infested. One infested pod contained 11 mature larvae and 1 of the third instar. These observations indicate that the seed capsules of algalia are well adapted to the feeding habits of pink bollworm larvae.

\section{Hibiscus}

The majority of the known host plants of the pink bollworm belong to the genus Hibiscus, of which at least 18 different species liave been reported from various countries of the world. Only three species, however, were found to be attacked by Pectinophora gossypiella in Puerto Rico namely, $H$. trilobus, $H$. bifurcatus, and $H$. sabdariffa.

Of these three species, Hibiscus trilobus is markedly preferred. ()t 87 pods collected 3 or 4 miles from a cotton area during the dead season at Boquerón, 14, or 16.1 percent, were infested. Many pupae were found inside the pods, a few pods containing three live pupae each. The involucre completely covers the seed capsule except for a small opening at the extreme tip. Some of the emerging moths 
were trapped in this enclosure and died. The seed capsules are about $1 \frac{1}{2}$ inches in diameter and $13 / 4$ inches in length, and it appears that they are well adapted to the feeding habits of this pest.

Hibiscus bifurcatus and $H$. sabdariffa were grown beside heavily infested cotton at Isabela and both became infested. In the former species 4.2 percent of the seed capsules were infested and 0.7 percent of the pods in the latter.

Hibiscus rosa-sinensis (var. Velvet Red) is a very common ornamental, grown as hedges, along roadsides, and in gardens, at all elevations. However this species rarely, if ever, produces seed capsules, although buds are produced in abundance during the entire year. Of 697 buds collected adjacent to heavily infested cotton, none was found to be infested. First-instar larvae were installed on 80 buds but none became infested.

Although Hibiscus schizopetalus is quite common, it rarely develops seed pods. The buds are small and not well adapted to the feeding habits of the larvae.

Both Taylor (1936) in Africa and Willcocks (1916) in Egypt report the presence of the pink bollworm in Hibiscus cannabinus; and one larva was taken in $H$. mutabilis by Loftin et al (1921) in Mexico. These two species are known to occur in Puerto Rico but only in limited numbers.

Of 568 seed pods of Hibiscus brasiliensis collected in an infested cotton-growing area ov'er a period of several months at Boquerón, none was found infested. This plant is quite numerous on the southern coast between Boquerón and Ponce.

No species of Hibiscus attacked by Pectinophora gossypiella in Puerto Rico is sufficiently numerous to be of any importance in maintaining this pest during the closed season of cotton production.

\section{Althama}

Although Althaea rosea (hollyhock) is occasionally attacked by the pink bollworm in Puerto Rico, it is not sufficiently abundant to be of any importance. Loftin, McKinney, and Hanson (1921) and Rude (1932) report it as a host plant in Mexico, and Willeocks (1916) in Egypt.

\section{AButilon}

Quantities of seed capsules of Abutilon hirtum were collected repeatedly near infested cotton and placed in rearing cages for emergence. From 502 pods collected at Boquerón, 2 pink bollworm 
moths emerged. From all the other collections no stage of this pest was ever recovered. The green pods are coated with a resinous secretion which might serve as a protection against certain insects.

It is interesting to note that Holdaway (1926) reports Abutilon octocarpus and A. amplum as host plants of Pectinophora gossypiella in West Australia and A. indicum in South India; McDonald (1931) records it from $A$. hypoleucum in Mexico but believes it would not survive on this host plant in the absence of domestic cotton; and King (1917) reports it from hanbuk (Abutilon sp.) in Africa. Britton (1924) reports the presence of $A$. indicum, A. umbellatum. and A. commutatum in Puerto Rico.

\section{Miscellaneous Records}

Three wild species of malvaceous plants are very common in Puerto Rico. These are Sida cordifolia, Malachra capitata, and Malvastrum sp. Large quantities of these plants were collected repeatedly near infested cotton and placed in rearing cages but no stages of the pink bollworm were ever found in them. However, species of both Sida and Malvastrum have been reported as host plants of the pink bollworm in other parts of the world.

Numerous seed capsules of Pariti tiliaceum were examined for the pink bollworm, but the results were negative. In most cases these fruiting forms were collected in cotton-growing areas heavily infested with the pink bollworm. Holdaway (1926) reports that this shrub is a primary host plant of a closely related species, Platyedra scutigera, in Queensland and New South Wales.

According to Hunter (1926), Cayla (1921) reports Bombax monguba (Bombaceae) as a host plant of Pectinophora gossypiella in Brazil. Numerous seed pods of a closely related species, Ceiba pentandra, were examined in Puerto Rico, but no stage of this pest was found in them.

\section{SUMMARY}

The seed pods of three malvaceous plants, Montezuma speciosis. sima (maga), Thespesia populnea (emajagüilla), and Abelmoschus esculentus (okra, or guingambó) were found to be important host plants of the pink bollworm in that they provide a continuous food supply for breeding during the dead season of cotton production. Several other plant species were attacked, namely. Abeloschus abelmoschus (algalia), Hibiscus sabidariffa (vina), Hibiscus trilobus, Hibiscus bifurcatus (buenas tardes), Abutilon hirtum (buenos días), 
and Althaea rosea (hollyhock, or varilla de San José). None of these species, however, is sufficiently numerous to be of any importance.

\section{Literature Cited}

Britton, N. L., \& Wilson, Percy. Scientific survey of Porto Rico and the Virgin Islands: New York Acad. Sci., 5 : 545-568, 1924. .

Cayla, V. A propos du "ver rose" du cottonier au Bresil.

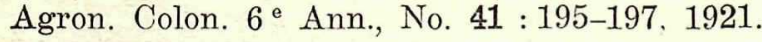

Fife, L. C. The pink bollworm of cotton in Puerto Rico during 1936 and recommendations for its control. Puerto Rico Agri. Expt. Sta. Agricultural Notes. 81, 9 pp. 1937.

Fullaway, D. T. Insects of Cotton in Hawaii. Hawaii Agr. Expt. Sta., Bull. 18, 27 pp., 1909.

Holdaway, F. G. The pink bollworm of Queensland. Bull. Ent. Research. $17: 67-83,1926$.

Hunter, W. D. The pink bollworm, with special reference to steps taken by the Department of Agriculture to prevent its establishment in the Unitd States. U. S. Dept. Agr., Dept. Bull. 1397, 30 pp., 1926.

King, H. H. The weed hanbuk (Abutilon sp.) and its relation to the cotton-growing industry in the Anglo-Egyptian Sudan. Ent. Bull. 7, 4 pp. Welleome Trop. Research Lab., Khartoum, 1917.

Loftin, U. C. Summary of work on pink bollworm. Rept. Virgin Island Agr. Expt. Sta. St. Croix, pp. 19-20. 1931.

Loftin, U. C., McKinney, K. B., \& Hanson, W. K. Report on investigations of the pink bollworm of cotton in Mexico. U. S. Dept. Agr.. Bull. 918, 64 pp., 1921.

McDonald, R. E. The present status of the pink bollworm in the southwest. Jour. Econ. Ent. 24 (4) : 790-795. 1931.

Ohlendorf, W. Studies of the pink bollworm in Mexico. U. S. Dept. Agr., Dept. Bull. 1374, 64 pp. 1926.

Rude, C. S. Host-plant studies of the pink bollworm. Jour. Econ. Ent. 25 (4) 751-759. 1932.

Taylor, T. H. C. Report on a year's investigation of Platyedra gossypiella (pink bollworm) in Uganda. (March, 1935, to April, 
1936). Uganda Protectorate Ann. Rept. Dept. Agr.. pt. 2, pp. 19-39. 1936.

Willard, H. F. Parasites of the pink bollworm in Hawaii. U. S. Dept. Agr., Tech. Bull. 19, 15 pp., 1927.

Willcocks, F. C. The insect and related pests of Egypt. v. 1. The insect and related pests injurious to the cotton plant, pt. 1. The pink bollworm. Sultanic Agr. Soc., Cairo. 339 pp., 1916.

Wolcott, G. N. Insectae Borinquenses. A revised annotated check-list of the insects of Puerto Rico. Jour. Agr. P. R., 20 (1), 627 pp., illus. (see pp. 492-497). 1936.

The infestation of young okra pods by pink bollworm in Puerto Rico. Jour. Agr. P. R. 15(4) : 395-398. 1931.

\& Seín, Jr., F. La oruga rosada de la cápsula del algodón. Ins. Expt. Sta. Circ. 95, 13 pp. 1931. 